\section{SD 12}

. N78

1891

Copy 1

\title{
IN THE MATTER
}

OF $\mathrm{THB}$

\section{INQUIRY CONCERNING}

THE

\section{ADMINISTRATION OF THE LAWS}

IN RELATION TO THE

FOREST PRESERVE

BY THE

FOREST COMMISSION, ETC.

REPORT ADOP'TED BY THE ASSEMBLT, APRIL 23, 1891.

ALBANY:

PRESS OF BRANDOW PRINTING COMPANY.

1891. 

IN THE MATTER

OF THE

\section{INQUIRY CONCERNING}

THE

\section{ADMINISTRATION OF THE LAWS}

IN RELATION TO THE

\section{FOREST PRESERVE}

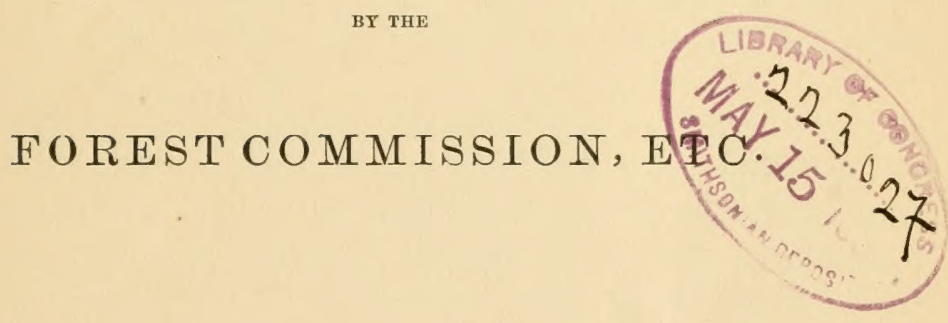

REPORT ADOPTED BY THE ASSEMBLY, APRIL 23, 1891.

ALBANY:

PRESS OF BRANDOW PRINTING COMPANY.

1891. 
5012.178 
IN THE MATTER OF THE INQUIRY CONCERNING THE ADMINISTRATION OF THE LAWS IN RELATION TO THE FOREST PRESERVE BY THE FOREST COMMISSION, ETC.

\section{To the Assembly:}

The Assembly on January 21, 1891, adopted the following:

"Resolved, That the committee on public lands and forestry be and it is hereby authorized to undertake and prosecute, during the present session of the Assembly, a general inquiry concerning the administration of the laws in relation to the forest preserve by the forest commission, and to report what, if any, changes in the present laws are necessary to protect the forests belonging to the State, with power of itself or by any sub-committee of its own members which it may appoint, to summon witnesses and to examine them under oath, to send for and examine books and papers and hold meetings at such times and places as to such committee or sub-committee may seem requisite and proper, and the committee is hereby authorized to employ a stenographer."

Pursuant to such resolution the committee on public lands and forestry respectfully reports that a large amonnt of testimony has been taken, extending over a considerable period of time and embracing an inquiry into the administration of the laws in relation to the forest commission, as well as what, if any, changes in the present laws are necessary to better protect the forests of the State and also as to the present condition of the Adirondack forests.

Your committee has been attended during the investigation by C. D. Adams, Esq., its connsel, while the forest commission have been represented by J. Newton Fiero, R. P. Anibal, and Albert Hessberg, Esqs.

The members of the forest commission have attended in person and have afforded every facility for the examination of their books, papers and employees.

The law by which the forest commission was established and its powers and duties mostly defined is chapter 283 , Laws of 1885 . In September of that year, Messrs. Townsend Cox, Sherman W. Knevals and Theodore B. Basselin, were appointed forest commissioners. 
Shortly thereafter they organized by the election of Commissioner Cox as president, which position he has continued to hold. Upon the expiration of the term of Commissioner Basselin, in 1888, he was reappointed for a full term of six years.

In May, 1886, the organization of the commission, as provided by law, being completed, there were received from the State Comptroller about 715,000 acres of land, of which more than 50,000 were in the Catskill region. This latter tract has since been increased by the action of Delaware and Ulster counties, until at the present time the State owns there a compact body of nearly 80,000 acres. The forest preserve outside of the Catskills has also since been inereased by the addition of lands in Oneida county, nearly 5,000 acres, and through the Comptroller's office by tax sales upwards of 60,000 acres, until at present the total of State lands in the sixteen counties within whose limits are all of the lands of the forest preserve, is 796,416 acres.

A concurrent resolution of the Legislature of 1890 , by which the commission was directed to consider the then recent message of the Governor in relation to the establishment of a State park in the Adirondacks, and to report to the Legislature the most effective methods to accomplish that end, imposed still another important duty upon the forest commission.

From the testimony and explanations given before your committee by the members of the forest commission and Assistant Warden Fox, who drew the boundaries as reported, the proposed Adirondack park, on which it was directed to report, has received intelligent corsideration by the commission, and the recommendations contained in its special report of January, 1891, to the Legislature, as to the size and location of the proposed park, and as to the methods of acquiring the lands within its boundaries, are the result of much careful deliberation, and cannot and should not be disregarded.

The act creating the forest commission has been amended from time to time, and by chapter 475 of the Laws of 1887 , known as the Hadley bill, further discretionary power was given to the commission in reference to its rights to recommend exchanges of lands without the probable Adirondack park for lands within such area as was likely to be set apart for park purposes.

Nothing was done under this act except as hereinafter stated, in as much as the commission deemed it inadvisable to act for some time until the park lines were actually fixed and established.

Subsequently the commission deeming the establishment of a park 
of great importance to the State, and the commission having arrived at a tacit understanding that the heart of the wilderness would most assuredly be included in the boundaries to be fixed so as to include and protect the headwaters of the rivers leading out of the great Adirondack forests, they determined to act upon the only application under the Hadley act that was made to the commission in proper form and was in compliance with such law, and they made a recommendation to exchange 12,000 acres of State lands to receive therefor at least 26,000 acres of private lands. The 12,000 acres being outside of the proposed park lines and the 26,000 acres being located in the center of the Adirondack forest.

Several other applications for exchange were made, which, however, were not accompanied by the consent to pay expenses of the application under the law, and consequently were not acted upon.

In 1890 the forest commission was also, with the approval and concurrence of the commissioners of the land office, authorized and empowered to purchase lands so located within such counties as include the forest preserve that shall be available for the purposes of the State park, at a price not to exceed one dollar and fifty cents per acre. No lands have as yet been purchased under this resolution, although several offers are before the commissioners, by reason of the fact that no offers were made until the fall of 1890 , since which time no opportunity has been given for the thorough examination of the lands, nor have the limits of the proposed park been fixed.

The principal matters to which the attention of the forest commission has necessarily been directed has been the checking of trespasses on State lands in the Adirondack region and the prevention of forest fires in that locality, both of which have been as appears by the reports of the special commission appointed under the Laws of 1886 , sources of great danger to the lands of the State.

At the time of the organization of the forest commission forest fires were numerous, and trespassing was carried on to a very large extent, there being no organized system for either the prevention of trespasses or putting out fires. The testimony taken shows that the commission has been diligent in the way of following up and prosecuting trespasses upon State lands and has been successful in substantially breaking up that practice which is now carried on only to a very limited extent. They have also organized methods for the prevention and putting out of forest fires which have resulted in a very great decrease in extent of injury done thereby.

This committee is of the opinion that nothing has been shown 
upon this investigation to in any wise affect the honesty or integrity of any member of the forest commission, and that the work of the commission has been discharged in a careful, intelligent and efficient manner.

The committee also recommends, under the authority to report, what if any changes in the present laws are necessary to protect the forests belonging to the State, the following legislation for the reasons stated under each recommendation :

First. An amendment to section 30 of chapter 283, Laws of 1885, establishing the forest commission and defining its powers and duties, which shall provide sufficient penalties for the violation of rules, which shall be made by the commission for the prevention and suppression of forest fires. As that act now stands the forest commission is authorized to make rules, but has no authority whatever to enforce them, nor is there any power lodged anywhere for that purpose. It is necessary such rule should be made and enforced and anthority should be given for such enforcement.

Second. A moderate sum should be provided for the purpose of experiment, under the direction of the forest commission, with reference to the replanting of denuded lands, which have been either exhausted by, cultivation, eroded by torrents, or injured by fire. A period of some fifteen years is necessary between the planting of trees and the obtaining of a sufficient growth for any practical purpose whatever. A considerable quantity of lands in the Adirondack region are denuded lands; it is an important question as to whether or not by a system of replanting they can be made of value to the State. The experiment should be commenced at as early a day as possible in order that it may be ascertained whether it is possible to bring back these denuded lands to their original condition as forests.

Third. That the compensation of firewardens be made a county instead of a town charge, and that the accounts be audited by the board of supervisors of the respective counties where the services are rendered. This seems only just, in view of the fact that in some of the towns of the Adirondack region the forest lands constitute the larger part of the taxable property within their limits. It seems an unreasonable burden that the town should be obliged to bear the expense of protecting these forests from fires through the action of the firewardens. When the benefit to be derived will inure to the entire community, the county would seem to be the proper authority to bear this expense.

Fourth. This committee further recommends that chapter 283, 
Laws of 1885 , be further amended so as to provide that the forest commission shall report annually to the Legislature a detailed statement of its receipts from all sources and its disbursements in every direction. This statement is now made through the Comptroller's office to the Legislature, but in view of the fact that moneys are received for trespasses directly by the commission, it would seem better that the commission itself should also report directly to the Legislature the whole amonnt of the moneys received and disbursed. All of which is respectfully submitted.

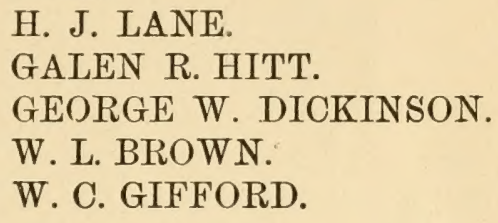

H. J. LANE.

GALEN R. HITT. GEORGE W. DICKINSON.

W. L. BROWN.

W. C. GIFFORD.

Adopted by the Assembly, April 23, 1891. 


LIBRARY OF CONGRESS

||| || || || ||||||||||||||||||||||||||||||

(

.

00014558925 